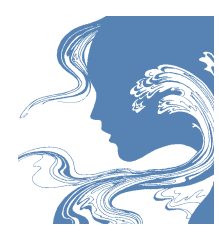

Гарданова Ж.Р.1-3, Воробьева К.А.1, Есаулов В.И.1, Седова Е.0.1, Ильгов В.И.1, Вепренцова С.Ю.1, Калина С.А. ${ }^{1}$

1 Федеральное государственное автономное образовательное учреждение высшего образования «Российский национальный исследовательский медицинский университет имени Н.И. Пирогова» Министерства здравоохранения Российской Федерации, 117997, г. Москва, Российская Федерация

2 Федеральное государственное бюджетное учреждение «Национальный медицинский исследовательский центр акушерства, гинекологии и перинатологии имени академика В.И. Кулакова» Министерства здравоохранения Российской Федерации, 117997, г. Москва, Российская Федерация

3 Федеральное государственное бюджетное образовательное учреждение высшего образования «Российский государственный социальный университет», 129226, г. Москва, Российская Федерация

\author{
Для корреспонденции \\ Гарданова Жанна Робертовна - \\ доктор медицинских наук, \\ старший научный сотрудник \\ терапевтического отделения \\ ФГБУ «НМИЦ АГП \\ им. акад. В.И. Кулакова» \\ Минздрава России \\ Адрес: 117997, г. Москва, \\ ул. Академика Опарина, д. 4 \\ Телесон: (495) 438-85-42 \\ E-mail: zanna7777@inbox.ru \\ https://orcid.org/0000-0002-9796- \\ 0846
}

\title{
Исследование склонности
} к девиации и особенностей уровня
жизнестойкости у подростков,
воспитывающихся в детских домах

Актуальность темы определяется возрастающими потребностями нашего общества
в поисках путей создания благоприятных условий для максимального развития личнос-
ти, эфффективности ее жизненного пути. Жизненный путь личности имеет единые для
всех «измерения», но способ разрешения жизненных проблем, построения жизни, удов-
летворенность ею глубоко индивидуальны. Материал и методы. В исследовании приняли участие 80 человек. Достоверность и обоснованность научных результатов обеспечивались опорой на базовые теоретикометодологические положения работы, применением методов исследования, адекватных предмету, целям и гипотезам исследования, достаточным объемом выборки и корректным использованием методов математической обработки эмпирических данных.

Проведено исследование показателей теста жизнестойкости С. Мадди (в адаптации Д.А. Леонтьева), теста смысложизненных ориентаций (СЖО) в адаптации Д.А. Леонтьева, методики диагностики склонности к отклоняющемуся поведению (СОП) А.Н. Орел, проведено сравнение показателей результатов у детей-сирот из социальных приютов и детей из полных семей.

Результаты. Общий уровень жизнестойкости у подростков из полных семей выше, чем у подростков-сирот. Для подростков из полных семей характерны наличие целей в жизни, удовлетворенность процессом жизни и большее ощущение осмысленности жизни, в отличие от социальных сирот. В действительности подростки из полных семей в большей степени готовы к риску, чем социальные сироты.

Общий уровень склонности к девиантному поведению у подростков-сирот выше, чем у подростков из полных семей. У социальных сирот выше уровень склонности к преодолению норм и правил, делинквентности, волевого контроля, для них более характерна аддиктивность.

Заключение. Особенности жизнестойкости подростков из детских домов проявляются низким уровнем принятия риска, вовлеченности в деятельность, заинтересованности и эмоциональной насыщенности жизни. Особенности склонности к девиантному пове- 
дению у социальных сирот проявляются в следующих показателях: преодолении норм и правил, аддиктивности, агрессивности, делинквентности поведения, целенаправленном проявлении девиантного поведения; общий уровень жизнестойкости у подростков из полных семей выше, чем у подростков-сирот. Для подростков из полных семей характерны наличие целей в жизни, удовлетворенность процессом жизни и большее ощущение осмысленности жизни, в отличие от социальных сирот; девиантное поведение у подростков-сирот выше, чем у подростков из полных семей. У социальных сирот выше уровень склонности к преодолению норм и правил, волевого контроля, для них более характерна аддиктивность. Общий уровень жизнестойкости и его компоненты, высокий уровень волевого контроля, обусловленный неудовлетворенностью жизнью, влияют на фрормирование у подростков из группы социальных сирот девиантного поведения.

Ключевые слова: подростки, социальные сироты, жизнестойкость, смысложизненные ориентации, отклоняющееся поведение, психологическое здоровье, девиантное поведение

Финансирование. Исследование не имело спонсорской поддержки.

Конфликт интересов. Авторы заявляют об отсутствии конфликта интересов.

Для цитирования: Гарданова Ж.Р., Воробьева К.А., Есаулов В.И., Седова Е.О., Ильгов В.И., Вепренцова С.Ю., Калина С.А. Исследование склонности к девиации и особенностей уровня жизнестойкости у подростков, воспитывающихся в детских домах // Репродуктивное здоровье детей и подростков. 2021. Т. 17, № 1. C. 49-62. D0I: 10.33029/18162134-2020-17-1-49-62

Статья поступила в редакцию 24.11.2020. Принята в печать 12.03.2021.

\section{Gardanova Zh.R.1-3, Vorobyova K.A.1, Esaulov V.I.1, Sedova E.0.1, Ilgov V.I.1, Veprentsova S.Yu.1,}

\section{Kalina S.A. 1}

1 N.I. Pirogov Russian National Research Medical University of the Ministry of Health of the Russian Federation, 117997, Moscow, Russian Federation

2 Kulakov Obstetrics, Gynecology and Perinatology National Medical Research Center of Ministry of Health of the Russian Federation,

117997, Moscow, Russian Federation

${ }^{3}$ Russian State Social University, 129226, Moscow, Russian Federation

\section{Study of the tendency to deviation and the characteristics of the level of vitality in adolescents brought up in orphanages}

The relevance of the topic is determined by the growing needs of our society in search of ways to create favorable conditions for the maximum development for the individual, the effectiveness of the life path. The life path of an individual has the same "dimensions" for all, but the way of solving life problems, building life, and satisfaction with it are deeply individual.

Material and methods. A total of 80 people took part in the study. The reliability and validity of scientific results was ensured by relying on the basic theoretical and methodological provisions of the work, the use of research methods adequate to the subject, goals and hypotheses of the study, a sufficient sample size and the correct use of methods of mathematical processing of empirical data.

Results. The general level of resilience among adolescents from full families is higher than among adolescents who are orphans. Teenagers from two-parent families are characterized by the presence of goals in life, satisfaction with the life process, and a greater sense of the meaningfulness of life, in contrast to social orphans. In fact, teenagers from two-parent families are more willing to take risks than social orphans.

The general level of inclination to deviant behavior among adolescents-orphans is higher than among adolescents from two-parent families. Social orphans have a higher level of propensity to overcome norms and rules, delinquency, volitional control, and addiction is more characteristic of them.

Conclusion. The characteristics of the resilience of adolescents from orphanages are manifested by a low level of risk acceptance, involvement in activities, interest and emotional saturation of life. The features of the propensity to deviant behavior in social orphans are manifested in the following indicators: overcoming norms and rules, addiction, aggressiveness, delinquent behavior, purposeful manifestation of deviant behavior, the general level of vitality in adolescents from complete families is higher than in adolescents-orphans. Teenagers from two-parent families are characterized by the presence of goals in life, satisfaction with the life process, and a greater sense of the meaningfulness of life, in contrast to social orphans, deviant behavior in teenage orphans is higher than in teenagers from complete families. Social orphans have a higher level of propensity to overcome norms and rules, volitional control, and addiction is more characteristic of them. The general level of resilience and its components, a high level of volitional control caused by dissatisfaction with life, affect the formation of deviant behavior in adolescents from the group of social orphans.

Keywords: adolescents, social orphans, resilience, life-meaning orientations, deviant behavior, psychological health, deviant behavior

Funding. The study had no sponsor support.

Conflict of interests. The authors declare no conflict of interests.

For citation: Gardanova Z.R. Study of the tendency to deviation and the characteristics of the level of vitality in adolescents brought up in orphanages. Reproduktivnoe zdorov'edetey i podrostkov [Pediatric and Adolescent Reproductive Health]. 2021; 17 (1): 49-62. D0I: 10.33029/1816-21342021-17-1-49-62 (in Russian)

Received 24.11.2020. Accepted 12.03.2021. 
B течение последних десятилетий психологическое здоровье личности считается неотъемлемым правом современного человека и целью современного развития общества. Критерии психологического здоровья включают удовлетворенность и чувство счастья и спокойствия, отражающие благополучие личности. В работах К.А. Абульхановой мы находим ссылки на понимание критериев психологического здоровья, предложенных Э. Динером, Р. Каном, Ф. Юстером [1, с. 89]. Э. Динер считает, что благополучие связано со счастьем личности как сочетания когнитивной и эмоциональной самооценки, которая состоит из 3 основных элементов: удовлетворенность жизнью, наличие приятных эмоций (позитивного настроения и стенических эмоций) и отсутствие неприятных эмоций [1, с. 90]. В то время как Р. Кан и Ф. Юстер считают, что психологическое благополучие - это позитивное состояние (счастье), которое колеблется от положительного полюса к отрицательному [1, с. 89].

Актуальность темы определяется возрастающими потребностями нашего общества в поисках путей создания благоприятных условий для максимального развития личности, эфффективности ее жизненного пути. Жизненный путь личности имеет единые для всех «измерения», но способ разрешения жизненных проблем, построения жизни, удовлетворенность ею глубоко индивидуальны [1, с. 97] (К.А. Абульханова).

Один из факторов снижения негативных последствий стрессоров для физического и психологического здоровья - это жизнестойкость, которая является устойчивой чертой личности. С. Кобаса считает, что жизнестойкость - это характеристика личности, которая выступает в качестве ресурса для формирования сопротивления от воздействий на психику стрессовых событий [2]. Как правило, жизнестойкость это структура, которая состоит из 3 компонентов: вовлеченность, чувство контроля и принятие риска. Жизнестойкие люди более самодостаточны в своих действиях и ориентированы на процесс деятельности, ее цели и смыслы. Они хорошо контролируют эмоциогенные ситуации и способны к самоопределению в сложной ситуации. Они понимают, что жизнь меняется, что каждая ситуация потенциально содержит в равной степени как возможности для саморазвития и самосовершенствования, так и ограничения и угрозы.

Проблема жизнестойкости актуальна для подросткового возраста, что подтверждается большим количеством исследований (начиная с исследований С. Мадди) в аспекте преодоления школьниками трудных жизненных ситуаций, подросткового одиночества. Рассматриваемые аспекты оказываются значимым фрактором в увеличении количества психических расстройств и суицидальных попыток. Подростки сталкиваются с огромным количеством проблем и кризисов. Их разрешение требует высокой адаптации, умения продуктивно справляться со стрессом, изменяющимися обстоятельствами жизни. Особую заинтересованность представляет анализ связей компонентов жизнестойкости (вовлеченности, контроля, принятия риска) с личностными ценностями [2].

Изучение жизнестойкости в подростковой среде весьма важно в современной психологии, так как это содействует фрормированию нового общества, в частности возможности личности устоять перед напряженными актуальными ситуациями и переоценить их как новую допустимость.

Зачастую большинство социально-психологических проблем подростков связано с девиантным поведением. Анализируя исследования в данной области, мы обратили внимание на то, что при актуальности и распространенности данной проблемы в подростковом возрасте мало изучены и освещены проблемы сущности девиантного поведения, личностных особенностей девиантных подростков. 
Понятие «жизнестойкость» (hardiness) было введено С. Мадди, когда он разрабатывал проблемы творческих способностей ребенка и урегулирование стрессовых ситуаций [3, с. 530]. По его мнению, эти проблемы вписываются в концепцию «жизнестойкость», потому что фрормируют ее. Человек развивается в процессе включенности, контроля и вызова, который ставят ему жизненные обстоятельства [3, с. 531]. Кроме того, у него обогащается потенциал, он учится справляться со стрессами, которые постоянно возникают у него на жизненном пути. По мнению автора, понятие «hardiness» показывает, насколько психологически человек живуч, насколько он может быть эффективным и здоровым, совладать со стрессовыми ситуациями [3, с. 532].

В своей работе С. Мадди, указывает, что «hardiness - это понятие, которое формирует у человека установку на выживаемость, hardiness - это поведение, при котором человек при любых обстоятельствах справляется с фракторами, которые провоцируют в его жизни стрессовые события, поэтому он в любом случае добивается личностного роста» [3, с. 530].

То, как человек относится к происходящему вокруг него, как он пользуется заложенными в него и его психику ресурсами, показывают, может ли человек в принципе противостоять околоэкстремальным и экстремальным стрессогенам, которые дают о себе знать каждый день.

С. Мадди считает, что основной характеристикой понятия «hardy» является «commitment», то есть «Включенность» [3, с. 537]. Это понятие определяет, как человек относится к себе, к окружающим, какой между ним и тем, что его окружает, характер взаимодействия. Включенность мотивирует человека быть лидером, здоровым, крепким, счастливым, оптимистически настроенным. Человек благодаря включенности может ощущать себя нужным, важным и значимым. У него появляются силы, которые помогают ему справляться со всеми трудностями, возникающими в жизни. В решение проблем он погружается полностью.

Иными словами, «hardy» - это аттитюд, который условно можно назвать контролем, под действием которого человек и находит в себе силы искать пути разрешения возникающих в жизни проблем, а не впадать в глубокую депрессию и чувствовать себя абсолютно беспомощным. Человек понимает, что жизнь бросает ему вызов, который он должен принять, с которым он должен справиться.

Р. Лазарус отмечает, что «hardiness» включает в себя несколько стратегий [4, c. 51]:

- стратегия противостоящего совладания; стратегия дистанцирования;

- стратегия самоконтроля; стратегия поиска социальной поддержки;

- стратегия принятия ответственности; стратегия избегания;

- стратегия планового решения проблемы; стратегия переоценки.

В зарубежной гуманистической психотерапии определяется ресурсный подход к пониманию жизнестойкости в работах И. Ялома, Р. Мэя, К. Роджерса, А. Маслоу, С. Хобфолла, В. Франкла.

Определение К. Роджерсом жизнестойкой личности - «открыта переживаниям», способна слышать себя, ощущать умом и сердцем окружающее и происходящее, признавая их неизбежность и непротиворечивость [5, с. 58]. Это экзистенциальный образ жизни, т.е. умение жить полной жизнью, осознавая неповторимость каждого момента жизни. Это органическое доверие, т.е. способность опираться в принятии решений на свои собственные чувства и воззрения, эмпирическая свобода, выражающаяся в возможности человека жить нестесненно, с учетом собственных желаний и настроя, без запретов и ограничений.

С. Хобфролл подробно раскрывает структуру ресурсов, из которых состоит понятие «жизнестойкость» [6, с. 49-82]. 
1. Материальные (доход, дом, одежда) и нематериальные (желания, цели) фракторы.

2. Внешние (социальная поддержка, семья, друзья, работа, социальный статус), внутренние (умения, навыки, способности, ценности и др.) характеристики.

3. Психические и физические состояния.

4. Волевые и эмоциональные характеристики, необходимые для преодоления трудных жизненных ситуаций.

Также мы пришли к выводу, что на рубеже веков в зарубежной отечественной психологии общим в понимании жизнестойкости было следующее определение: жизнестойкость - это ресурсная способность организма бороться со стрессовыми ситуациями и самореализовываться, развивающаяся на фоне установок активного взаимодействия с жизненными ситуациями.

Рассматривая точку зрения Э. Фромма о социальной детерминации личности, мы полагаем, что жизнестойкость детерминируется не только индивидуальной системой ценностей, но и ценностями общества, в котором личность развивается, - это язык, территория, культура, самосознание, этнокультурные особенности [7, с. 189].

Итак, проводя анализ понятия «жизнестойкость», в зарубежных исследованиях мы определили, что жизнестойкость характеризуется как действенное преодоление кризисных ситуаций на основании имеющихся жизненных ценностей у личности, ориентаций, целей.

В отечественной психологии феномен жизнестойкости изучался достаточно подробно (Д.А. Леонтьев, Л.А. Александрова, Е.И. Рассказова, С.В. Книжникова, Р.И. Стецишин, С.А. Богомаз, М.В. Логинова и т.д.). Рассмотрим развитие понимания жизнестойкости в отечественной психологии.

Способность личности выходить за пределы собственного «Я», принимая во внимание также и мнения окружающих по поводу своей социальной деятельности, рассматри- вает А.А. Реан как жизнестойкость личности в социуме [8, с. 145]. Личность использует все свои способности, возможности и умения, чтобы добиваться не только собственного совершенства, но и благополучия окружающих, тем самым уводя человека от эгоцентризма, проявляющегося в поисках только личного счастья.

Д.А. Леонтьев утверждал, что жизнестойкость есть черта, характеризующаяся мерой преодоления человеком заданных обстоятельств, но, главное, мерой преодоления личности самой себя [9, с. 95]. Именно воля, сила внутреннего «я» человека, ориентация составляют феноменологию личностного потенциала, его жизнестойкости [9, с. 97]. Жизнестойкость молодежи является комплексом установок. В этот комплекс также входят диспозиции, которые позволяют человеку формировать жизненный проект позитивного содержания, чтобы он мог объективно оценить свои возможности, ресурсы, которыми он располагает. Все это помогает ему быстро и правильно разрешать проблемы, которые возникают у него в жизни.

Л.А. Александрова рассматривала жизнестойкость как интегральную способность, лежащую в основе адаптации личности [2, с. 82-90].

С.В. Книжникова высказывала идею о том, что жизнестойкость есть интегральная характеристика личности, которая позволяет сопротивляться отрицательным воздействиям среды, успешно преодолевать жизненные трудности, трансорормируя их в ситуации развития [8, с. 14].

М.В. Логинова утверждала, что жизнестойкость есть «сложное структурированное психическое образование, которое определяется как развивающаяся система убеждений, помогающих развитию готовности управлять системой повышенной сложности» [10, с. 31].

Человек должен овладеть внешними обстоятельствами, чтобы стать творцом своей индивидуальной истории. В этом видит смысл жизнестойкости М.В. Логи- 
нова. Возможностью развития жизнестойкости она считает творчество как источник, позволяющий «индивиду полностью раскрыть свои сущностные силы, подлинные человеческие способности и внести свой оригинальный, индивидуальный вклад в ценности общества, в обогащение духовного мира человека» [9, с. 32].

Анализируя феномен жизнестойкости в работах зарубежных и отечественных исследователей, мы видим, что жизнестойкость - это сложное психологическое образование с точки зрения представленности в свойствах индивидуальности человека. Эти свойства включают такие компоненты, как психофизиологический, социальнопсихологический и личностно-смысловой. Их можно видеть в отдельных ситуациях как единый комплекс, помогающий успешной саморегуляции стрессовых состояний.

Наосновании исследований зарубежных и отечественных психологов мы пришли к выводу, что феномен жизнестойкости имеет связи с разными структурами психики на уровне функционирования психофизиологических процессов и проявления личностных образований.

В зарубежной и отечественной психологии общим в понимании жизнестойкости было ее определение как ресурсной способности организма бороться со стрессовыми ситуациями и самореализовываться, развивающейся на фоне установок активного взаимодействия с жизненными ситуациями.

В ходе теоретического анализа понимания термина «жизнестойкость» в психологической науке мы пришли к следующему: это интегративное свойство личности, позволяющее преодолевать трудности в достижении цели, характеризующееся высокой степенью рефлексии, оптимальной саморегуляцией и готовностью к самоопределению, детерминируемоежизненными ценностями и индивидуально-типологическими особенностями. Далее мы подробно изучим особенности, влияющие на формирование жизнестойкости.
С.Т. Сулейманова в своей диссертации показывает, что российское общество в настоящее время находится в состоянии аномии: стирается грань между социальнопозитивным и негативным поведением $[11$, с. 25]. Отсутствие какой-либо идеологии, значимых ценностных ориентаций становится элементом криминальной субкультуры [11, с. 25].

В исследованиях Е.К. КазаринойВолшебной, И.Г. Комиссаровой, В.Н. Турченко указывается, что основными ценностями ранней юности являются семья, друзья и здоровье, а далее следуют хорошая работа, деньги и справедливость (значение этой ценности в последнее время возрастает, что объясняет большое количество молодежи на оппозиционных митингах) [11, с. 121-126]. Замыкает собрание главных жизненных ценностей религиозная вера - к вере возрождается интерес молодежи. Так, к примеру, если в обществе ценится хорошая работа, то современный молодой человек будет нацелен на достижение карьеры и приложит волевые усилия к ее достижению.

Другими словами, ценности и ценностные ориентации способны изменяться под влиянием референтной группы и на основании собственных интересов и выборов. В свою очередь, они оказывают влияние на уровень жизнестойкости и структурные компоненты данного качества.

В течение жизни ценности личности изменяются в зависимости от ситуации, но три иерархические ступени влияния - это семья, государство и общество. Ценности принимаются, в процессе эксперимента отбрасываются, вырабатывается собственная система ценностей - об этом пишет в своем исследовании Д.К. Копкова [12, с. 484485]. В данном процессе происходит влияние на формирование жизнестойкости и ее качеств (воли, временной перспективы, саморефлексии). При разности семейных, социальных условий личность обусловлена отличиями той группы и ее ценностей, в которой она находится. В соответствии с этим 
уровень жизнестойкости личности обусловливается в зависимости от типа ее семьи и социальных условий жизни.

Жизнестойкость формируется на 3 уровнях: государственном, внутрисемейном, социальном. Внутрисемейное влияние создает передачу ценностей, восприятия мира, обусловливающие стремление к самореализации и самостоятельности. На государственном уровне жизнестойкость формируется в качестве профилактики, стратегий жизненного плана и избегания суицидальных рисков. Влияние социального окружения автономно и определяется мнением рефрерентной группы.

Влияние этих 3 социальных сфрер различно, наибольшим воздействием обладает семейное влияние. Ввиду этого нами было сделано предположение о том, что в зависимости от включенности в тип социальной структуры тип жизнестойкости будет отличаться.

С точки зрения С. Мадди, наиболее подходящим (сенситивным) периодом для формирования жизнестойкости является подростковый возраст [3, с. 32]. Прежде чем начать подробный разбор особенностей формирования жизнестойкости подростков, проживающих в условиях детского дома, целесообразно рассмотреть их психологические особенности.

Целой плеядой авторов (И.В. Дубровина, В.С. Мухина, Т.В. Корнилова [13] и др.) было проведено исследование, направленное на определение уровня субъективного контроля, результаты которого указывают, что экстернальная позиция, занимаемая подростками, лишенными родительского попечительства, лежит в основе неполноценной структуры их деятельности, начиная с этапов целеполагания и завершая этапами контроля. Неполное осуществление ориентировочной основы деятельности не позволит четко и правильно выбрать стратегию деятельности (планирование) и способы достижения этих целей. Особенности контроля подростков, воспитывающихся в детских домах, не позволяют четко и правильно спланировать деятельность, а также выбрать способы достижения целей, потому что в своих неудачах они винят в первую очередь окружающих.

Рассматривая особенности мотивации как компонента жизнестойкости, мы обратились к работам Н.Б. Евстифреевой [10], где особенности фрормирования потребностно-мотивационной сферы воспитанников детских домов обусловлены основными проблемами общения и взаимодействия. Мотивация воспитанников детского дома характеризуется следующими компонентами: «преобладанием мотива избегания неудач над мотивом достижения успеха» [10, с. 84].

В работах И.В. Дубровиной отмечаются особенности самооценки подростков: так, подросткам из детского дома присущи заниженная самооценка, неуверенность в себе как устойчивое качество личности, суженность спектра оцениваемых у себя личностных качеств, формирование негативного представления об их оценке окружающими [13, с. 32].

Рассматривая особенности готовности К профессиональному самоопределению как компонента жизнестойкости, мы обратились к работам Е.А. Байер [14]. Автор указывает, что профессиональные намерения подростков, оставшихся без попечения родителей, формируются на основе их низкой личностной активности в процессах профессионального самоопределения, дефицита информации о мире профессий и о возможностях профессионального развития, а также на основе слаборазвитого самосознания и неполного представления о себе в частности. Недостаточная социальная зрелость, незаинтересованность в получении профессии, низкие познавательные способности, неумение приспосабливаться к новой социальной среде, незнание современных условий жизни затрудняют процесс профрессионального самоопределения данной категории подростков.

Таким образом, особенности профессиональной мотивации подростков-сирот 
указывают на ее низкий уровень. Это происходит из-за недостаточной социальной зрелости, незаинтересованности в получении профессии, низких познавательных способностей, неумения приспосабливаться к новой социальной среде, незнания современных условий жизни.

Рассматривая особенности готовности к риску как компонента жизнестойкости в работах Е.А. Байер [13], мы наблюдаем, что у детей-сирот склонность к риску находится на высоком уровне, показатель контроля, наоборот, занижен. Они не способны сдерживать свои эмоции, заранее планировать и контролировать свое поведение. Уровень вовлеченности у них достаточно высокий. Сироты умеют выслушать собеседника и высказать уверенно свое мнение, они решительны, но не умеют адекватно воспринимать мнение других и согласовывать позиции, не способны вовремя отступить и договориться с партнером.

Для изучения общего уровня жизнестойкости подростков из детских домов мы опирались на работу С.В. Книжниковой [15]. Результаты проведенного исследования указывают на то, что подростки имеют низкий уровень жизнестойкости в целом по всем ее компонентам. Это может свидетельствовать о том, что воспитанники детского дома характеризуются низким уровнем эффрективности преодоления стрессовых ситуаций, что они подвержены депрессивным состояниям, апатии, отличаются отличаются неспособностью справляться с возникающими в процессе жизнедеятельности ситуациями, неуверенностью в себе, в своих силах, в своих поступках. Также это показывает, что подростки имеют низкие способности творчески и активно приспособиться к социальной среде, среде сверстников, что мешает им реализоваться в разных видах деятельности. Кроме того, они отличаются высоким уровнем конфликтности и склонностью к совершению асоциальных поступков.

Итак, на основании работ Е.А. Байер, Г. Крайга, В.Д. Менделевич, М.В. Логинова,
А.А. Реан, А.Д. Гонеева, S.R. Maddi [16-18] и др., анализируя проблему особенностей формирования жизнестойкости у подростков из детских домов, мы пришли к следующим выводам.

- Характеристикой подростков, воспитывающихся в детских домах, является низкий уровень развития коммуникативной и эмоциональной сфер.

- Рассматривая особенности ссрормированности компонентов жизнестойкости у подростков детских домов, отметили, что у них наиболее ярко выражен такой показатель жизнестойкости, как склонность к риску, показатель контроля, наоборот, занижен. Общий уровень жизнестойкости низкий, подростки социально не реализованы и не приспособлены к жизни. Нами была составлена схема компонентов жизнестойкости, представленная на рис. 1.

\section{Материал и методы}

В исследовании приняли участие 80 человек, из них подростки социальные сироты (40 человек) и подростки из полных семей (40 человек). Цель - исследовать взаимосвязь особенностей низкого уровня жизнестойкости и склонности к девиантному поведению у подростков социальных сирот.

\section{Методики}

1. Тест жизнестойкости С. Мадди (в адаптации Д.А. Леонтьева)

Цель методики: диагностика жизнестойкости.

Описание методики: Диагностика жизнестойкости реализуется в 3 сфрерах: вовлеченность, контроль, принятие риска. Оценка производится путем сравнения отклонения от среднего значения и стандартного отклонения общего балла испытуемого. Общее количество вопросов в опроснике -45 .

2. Тест смысложизненных ориентаций (СЖО) в адаптации Д.А. Леонтьева

Цель методики: диагностика смысла жизни, который может быть найден че- 


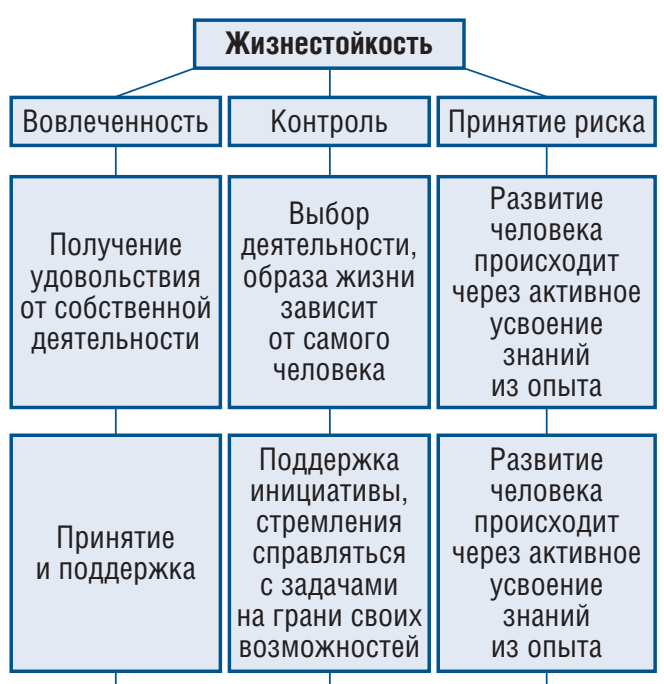

Условия развития компонентов жизнестойкости

Рис. 1. Схема компонентов жизнестойкости

ловеком либо в будущем (цели), либо в настоящем (процесс) или прошлом (результат), либо во всех 3 составляющих жизни.

Описание методики: Тест СЖО содержит 20 пар противоположных утверждений, отражающих представление о фракторах осмысленности жизни личности. Диагностируются следующие параметры: цель в жизни, эмоциональная насыщенность жизни, результативность жизни, локус контроля Я, локус контроля - жизнь.

Результаты исследования: по методике «Тест жизнестойкости» С. Мадди (в адаптации Д.А. Леонтьева) мы получили результаты у социальных сирот и подростков из полных семей, представленные на рис. 2. Расчет производили по среднему значению.

Рассмотрим фракторы жизнестойкости группы социальных сирот: вовлеченность в группе низкая, общегрупповое среднее значение - 28,4. Дети не получают удовольствия от собственной деятельности: учебной, игровой, социальной. В группе отсутствуют интерес к деятельности и включенность в деятельность.

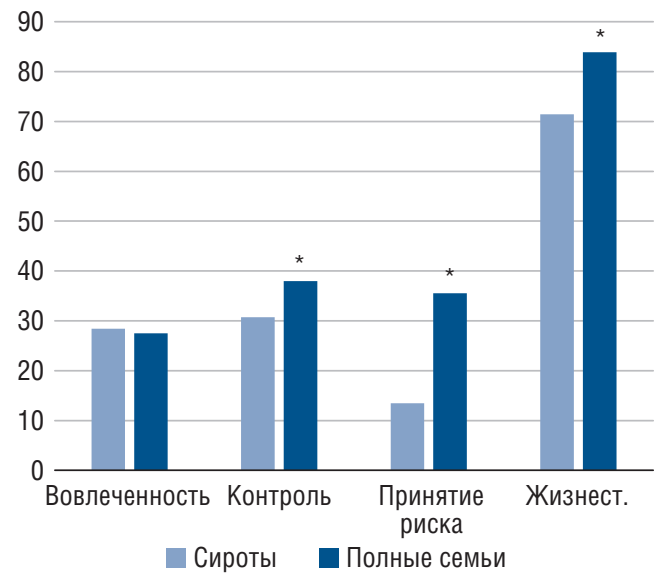

Рис. 2. Особенности факторов жизнестойкости у социальных сирот и подростков из полных семей

${ }^{*} p<0,05$.

Контроль у подростков-сирот в группе в норме: общегрупповое среднее значение - 30,72. Большинство подростков адекватно воспринимают изменения в своей жизни, даже если эти изменения могут быть отрицательными. Присутствует базовое доверие к миру, что является положительной характеристикой для группы сирот с учетом полученного ими жизненного опыта.

Принятие риска у социальных сирот находится в норме: общегрупповое среднее значение - 13,4. Воспитанники детского дома рассматривают произошедшие с ними события как часть жизненного опыта. Возможно, такие результаты являются эфффективной работой психолога с данной группой детей.

Примечательно, что по итоговым значениям в группе жизнестойкость находится в норме: общегрупповое среднее значение - 71,42. Благодаря развитости предыдущих компонентов жизнестойкости общая суммарная мера жизнестойкости у воспитанников детского дома позволяет эффективно справляться со стрессом. 


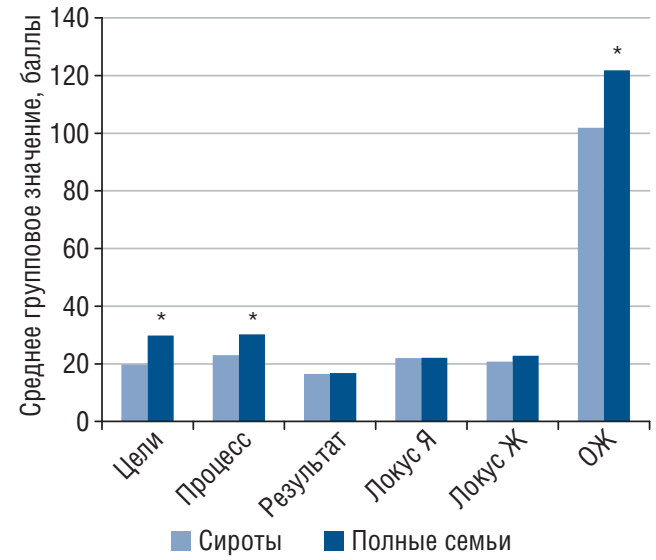

Рис. 3. Особенности осмысленности жизни у социальных сирот и подростков из полных семей

\section{Результаты}

Группы полных семей. Как мы видим на рис. 1, у подростков из полных семей вовлеченность находится на низком уровне: общегрупповое среднее значение $-27,47$. Дети не получают удовольствия от собственной деятельности: учебной, игровой, социальной. В группе отсутствуют интерес к деятельности и включенность в деятельность.

Контроль у подростков из полной семьи в группе высокий - 38. Большинство подростков убеждены в том, что их решения влияют на результат происходящего. Стремятся к контролю жизненных ситуаций.

На рис. 1 изображено, что принятие риска находится на высоком уровне: общегрупповое среднее значение - 35,52. Дети стремятся к риску и стараются использовать новые жизненные ситуации как часть опыта.

По итоговым значениям в группе показатель жизнестойкости находится на уровне нормативных показателей: общегрупповое среднее значение - 83,87. Благодаря развитости предыдущих компонентов жизнестойкости общая суммарная мера жизнестойкости позволяет эффективно справляться со стрессом.
Диагностируются следующие параметры:

Субшкала 1 (цель в жизни).

Субшкала 2 (процесс жизни).

Субшкала 3 (результат жизни).

Субшкала 4 (локус контроля - Я).

Субшкала 5 (локус контроля - жизнь).

Осмысленность жизни (ОЖ).

Характеризуя группу социальных сирот по методике жизнестойкости С. Мадди, мы получаем портрет, в котором выявлены следующие особенности: у воспитанников детского дома уровень жизнестойкости в норме. Они способны принимать стрессовые ситуации как часть опыта, готовы к ситуациям, не зависящим от их действий. Однако при таком отношении к жизненным изменениям у детей утратился интерес к деятельности. За отсутствием интереса вполне могут скрываться страх получения негативного опыта, апатия, депрессивные переживания, связанные с осознанием того, что активность приносит в жизнь как положительный, так и отрицательный опыт.

Характеризуя группу подростков из полных семей по методике жизнестойкости С. Мадди, мы получаем портрет, в котором выявлены следующие особенности: у подростков из полных семей уровень жизнестойкости в норме. Однако при этом они стремятся к риску, принимая его как опыт, к повышенному контролю жизненных событий. Эти составляющие указывают на невротический конфликт интереса и страха перед жизнью, на фоне которого снижается интерес к деятельности.

Результаты анализа смысложизненных ориентаций по опроснику Д.А. Леонтьева суммированы на рис. 3.

Графические результаты позволяют определить, что удовлетворенность самореализацией у социальных сирот находится ниже среднего уровня - 20,75. Полученные баллы свидетельствуют о неудовлетворенности прожитой частью жизни, самореализацией в этой жизни. 
Низкий уровень по «локусу контроля» Я $(21,97)$ означает, что дети из детских домов не верят в собственные силы, не обладают свободой выбора, чтобы построить свою жизнь по своему представлению о ней, не умеют контролировать события в своей жизни.

Они не могут контролировать свою жизнь, свободно принимать решения и воплощать их в жизнь. Другими словами, они убеждены, что бессмысленно загадывать на будущее, что их жизнь не подвластна сознательному контролю.

Процесс жизни - 23,0 ниже среднего значения. Это означает, что процесс жизни или интерес к ней и ее эмоциональная насыщенность довольно низкие. Сироты не удовлетворены своей жизнью в настоящем, планы на будущее они не выстраивают, они живут только сегодняшним днем.

Полученные результаты «цели жизни» свидетельствуют о средних значениях в 19,75, что свидетельствует о направленности испытуемых на будущую перспективу жизни.

Удовлетворенность самореализацией у подростков из полных семей находится на среднем уровне - 22,8. Полученные баллы свидетельствуют о среднем уровне удовлетворенности группы прожитой частью жизни, самореализацией себя в этой жизни, эмоциональной насыщенностью жизненных событий.

Низкий уровень по шкале «локус контроль» $(22,1)$ означает , что для подростков характерно отсутствие веры в собственные силы, ощущение отсутствия свободы выбора, чтобы построить жизнь по своему представлению о ней или желание больших возможностей и свобод, в сочетании с отсутствием умения контролировать события в своей жизни.

По анализу шкалы «процесс жизни» получены результаты - 30,2, что свидетельствует о высоком уровне интереса $\mathrm{k}$ жизни. Подростки из полных семей удовлетворены своей жизнью в настоящем, они выстраивают планы на будущее, жизнь для них наполнена смыслом в настоящем моменте.

Полученные результаты «цели жизни» характеризуются высокими значениями 29,8. В группе респонденты обладают целеустремленностью и направленностью в завтрашний день.

Рассматривая общий уровень осмысленности жизни $(121,85)$ у подростков из полных семей, мы видим высокие результаты, наличие смыслов в реальной жизни, отсутствие гедонистических мотивов или планов без опоры на реальность.

По итогам диагностики уровня осмысленности жизни мы получили психологический портерт осмысленности жизни.

Основные жизненные задачи - это удовлетворение актуальных в настоящий момент потребностей, связанных с удовольствиями и увлечениями. Им характерны представления о жизни как об одном дне, без проектирующих мыслей о своих потребностях в будущем и тенденции к построению планов. Система ценностей носит узкий характер и в большей степени ориентирована на ежеминутное получение удовольствий. Многие отмечают, что их жизнь не поддается контролю, ощущают себя слабовольными и не способными самостоятельно принимать решения в своей жизни. Присутствует линия перспективы будущего, выраженная в целях, однако она выражена в среднем.

Смысл жизни представлен в большей степени фраталистическими убеждениями. По методике СОП мы получили следующие результаты по группам. Изобразим полученные данные психологического портрета осмысленности жизни у подростков из полных семей и у социальных сирот графически на рис. 4.

Сироты склонны к преодолению норм и правил $(52,37)$, аддиктивности $(53,07)$, агрессивности $(49,8)$, делинквентности поведения $(55,55)$.

Отметим, что делинквентное поведение в подростковом возрасте совершается 


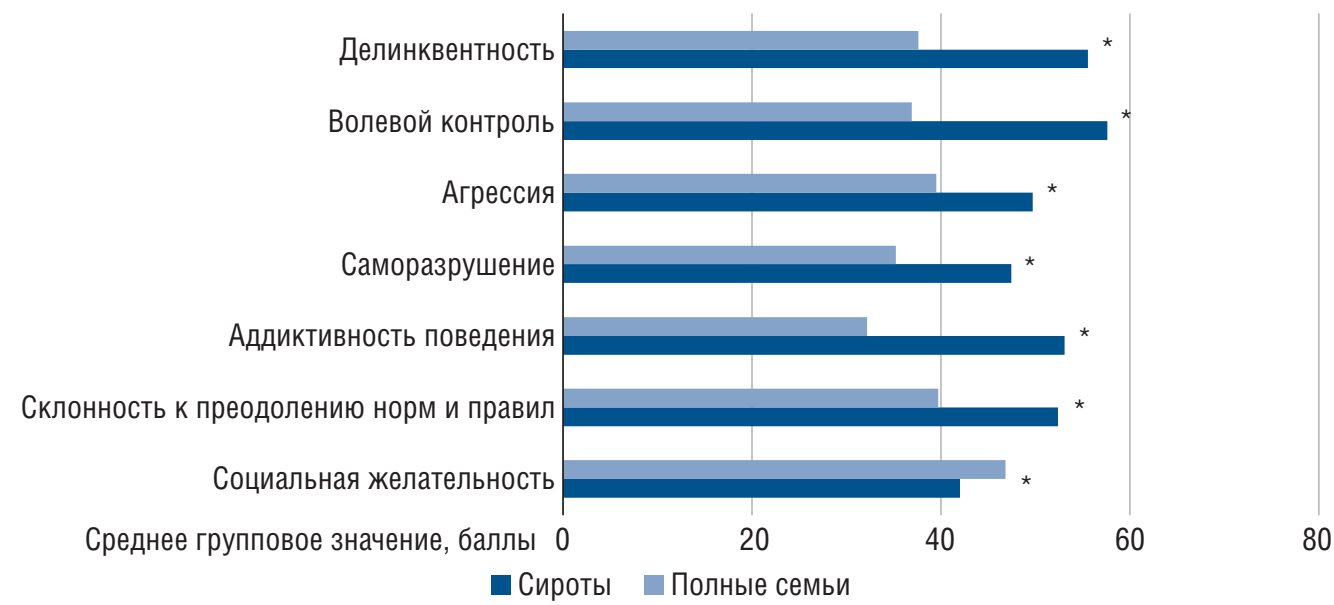

Рис. 4. Особенности склонности к девиантному поведению у социальных сирот и подростков из полных семей

целенаправленно и осознанно, так как волевой контроль находится на высоком уровне $(57,62)$.

\section{Выводы}

1. Особенности жизнестойкости подростков из детских домов проявляются в следующих показателях: низком уровне принятия риска, вовлеченности в деятельность, заинтересованности и эмоциональной насыщенности жизни.

2. Особенности склонности к девиантному поведению у социальных сирот проявляются в следующихпоказателях: преодолении норм и правил, аддиктивности, агрессивности, делинквентности поведения, целенаправленном проявлении девиантного поведения.

3. Общий уровень жизнестойкости у подростков из полных семей выше, чем у подростков-сирот. Для подростков из полных семей характерны наличие целей в жизни, удовлетворенность процессом жизни и большее ощущение осмысленности жизни, в отличие от социальных сирот. Если говорить о девиантном поведении: у подростков-сирот он выше, чем у подростков из полных семей. У социальных сирот выше уровень склонности К преодолению норм и правил, делинквентности, волевого контроля, для них более характерна аддиктивность.

4. Общий уровень жизнестойкости и его компоненты, высокий уровень волевого контроля, обусловленный неудовлетворенностью жизнью, влияют на формирование у подростков из группы социальных сирот девиантного поведения.

\section{Сведения об авторах}

Гарданова Жанна Робертовна (Zhanna R. Gardanova) - доктор медицинских наук, профессор, заведующий кафедрой психотерапии ФГАОУ ВО РНИМУ им. Н.И. Пирогова Минздрава России, старший научный сотрудник ФГБУ «НМИЦ АГП им. В.И. Кулакова» Минздрава России (Москва, Российская Федерация)

E-mail: zanna7777@inbox.ru

https://orcid.org/0000-0002-9796-0846 
Воробьева Ксения Азатовна (Kseniya A. Vorobyova) - ассистент кафедры психотерапии ФГАОУ ВО РНИМУ им. Н.И. Пирогова Минздрава России (Москва, Российская Федерация)

E-mail: ksushavor@mail.ru

https://orcid.org/0000-0001-8992-5066

Есаулов Владимир Игоревич (Vladimir I. Esaulov) - ассистент кафредры психотерапии ФГАОУ ВО РНИМУ им. Н.И. Пирогова Минздрава России (Москва, Российская Федерация)

E-mail: v-esaulov@yandex.ru

https://orcid.org/0000-0002-0123-4752

Седова Екатерина Олеговна (Ekaterina O. Sedova) - кандидат психологических наук, доцент кафедры психотерапии ФГАОУ ВО РНИМУ им. Н.И. Пирогова Минздрава России (Москва, Российская Федерация)

E-mail: eosedova@mail.ru https://orcid.org/0000-0003-0798-1297

Ильгов Вячеслав Иванович (Vyacheslav I. llgov) - ассистент кафедры психотерапии ФГАОУ ВО РНИМУ им. Н.И. Пирогова Минздрава России (Москва, Российская Федерация)

E-mail: ilgov.v@mail.ru

https://orcid.org/0000-0002-4297-1679

Вепренцова Светлана Юрьевна (Svetlana Yu. Veprentsova) - кандидат психологических наук, доцент кафедры психотерапии ФГАОУ ВО РНИМУ им. Н.И. Пирогова Минздрава России (Москва, Российская Федерация)

E-mail: 715@bk.ru

https://orcid.org/0000-0002-0149-0182

Калина Светлана Андреевна (Svetlana A. Kalina) - ассистент кафедры психотерапии ФГАОУ ВО РНИМУ им. Н.И. Пирогова Минздрава России (Москва, Российская Федерация) E-mail: s.a.kalina@mail.ru

https://orcid.org/0000-0003-4385-3276

\section{Литература}

1. Абульханова К.А. Акмеология: учебник для вузов. Москва : РАГС, 2002. $681 \mathrm{c.}$

2. Cunningham C.J.L., De La Rosa G., Jex S.M. The dynamic influence of individual characteristics on employee wellbeing: a review of the theory, research, and future directions [Electronic resource]. 2008. DOI: https://doi.org/10.1017/ СBO9780511490064.013

3. Мадди С.Р. Теории личности: сравнительный анализ. Санкт-Петербург : Речь, 2002. 539 с.

4. Лазарус Р.С. Эмоция как процесс защиты. СанктПетербург : Питер, 2004. 560 с.

5. Роджерс К.Р. Консультирование и психотерапия: новейшие подходы в психологической практике : пер. с англ. Москва : ИОИ, 2015. 197 с.

6. Hobfoll S.E., Dunahoo C.L., Ben-Porath Y., Monnier J. Gender and coping: the dual-axis model of coping // Am. J. Community Psychol. 1994. Vol. 22, N 1. P. 49-82.

7. Фромм Э. Бегство от свободы. Москва: АСТ, 2017. $287 \mathrm{c}$.
8. Реан А.А. Психология личности. Санкт-Петербург : Питер, 2017. 286 с.

9. Леонтьев Д.А. Психология смысла Москва: Смысл, 2003. 487 c.

10. Логинова М.В., Психологическое содержание жизнестойкости подростков : дис. ... канд. психол. наук. Москва : Мысль, 2010. 153 с.

11. Сулейманова С.Т. Делинквентное поведение подростков в современном российском обществе: факторы и социальный контроль: автореф. дисс.... канд. социол. наук. Пенза, 2006. 25 с

12. Копкова Д.К. Формирование ценностных ориентиров и установок у подростка // Молодой ученый. 2015. № 17. С. $484-485$.

13. Дубровина И.В. Практическая психология в лабиринтах современного образования: монография. Москва, 2014. 455 c.

14. Байер Е.А. Научная статья: «Исследование жизнестойкости у детей-сирот в учреждении государственной 
поддержки детства как залога успешной интеграции в быстро меняющемся социуме» // Ученые записки университета имени П.Ф. Лесгафта. 2009. № 4. C. $6-11$.

15. Книжникова С.В. Педагогическая профилактика суицидального поведения на основе формирования жизнестойкости. Краснодар : АВС-полиграфия, 2009. $111 \mathrm{c}$.
16. Крайг Г. Психология развития. Санкт-Петербург Питер, 2011. 939 с.

17. Менделевич В.Д. Психология девиантного поведения. Санкт-Петербург : Речь, 2005. 444 с.

18. Гонеев А.Д., Лифинцева Н.И., Ялпаева Н.В. Основы коррекционной педагогики: учебное пособие для студентов высших педагогических учебных заведений / под ред. В.А. Сластенина. Москва, 2017. 701 с.

\section{References}

1. Abulkhanova K.A. Acmeology: Textbook for universities. Moscow: RAGS, 2002: 681 p. (in Russian)

2. Cunningham C.J.L., De La Rosa G., Jex S.M. The dynamic influence of individual characteristics on employee wellbeing: a review of the theory, research, and future directions [Electronic resource]. 2008. DOI: https://doi.org/10.1017/ CBO9780511490064.013

3. Maddy S.R Theories of personality: a comparative analysis. Saint-Petersburg: Rech', 2002: 539 p. (in Russian)

4. Lazarus R.S Emotion as a process of protection. SaintPetersburg: Piter, 2004: 560 p. (in Russian)

5. Rogers K.R Counseling and psychotherapy: the latest approaches in psychological practice: trans. from English. Moscow: IOI, 2015: 197 p. (in Russian)

6. Hobfoll S.E., Dunahoo C.L., Ben-Porath Y., Monnier J. Gender and coping: the dual-axis model of coping. Am J Community Psychol. 1994; 22 (1): 49-82.

7. Fromm E. Escape from freedom. Moscow: AST, 2017: 287 p. (in Russian)

8. Rean A.A. Psychology of personality. Saint-Petersburg: Piter, 2017: 286 p. (in Russian)

9. Leont'ev D.A. Psychology of meaning. Moscow: Smysl, 2003: 487 p. (in Russian)

10. Loginova M.V. Psychological content of adolescents' resilience: Diss. Moscow: Mysl', 2010: 153 p. (in Russian)
11. Suleymanova S.T. Delinquent behavior of adolescents in modern Russian society: factors and social control: Autoabstract of Diss. Penza, 2006: 25 p. (in Russian)

12. Kopkova D.K. Formation of values and attitudes in a teenager. Molodoy uchoniy [Young Scientist]. 2015; (17): 484-5. (in Russian)

13. Dubrovina I.V. Practical psychology in the labyrinths of modern education: Monograph. Moscow, 2014: 455 p. (in Russian)

14. Bayer E.A. Scientific articleЖ $Ж$ Research on the resilience of orphans in the institution of state support for childhood as a guarantee of successful integration in a rapidly changing society». Uchenie zapiski instituta imeni P.F. Lesgafta [Scientific Notes of University named after P.F. Lesgaft]. 2009; (4): 6-11. (in Russian)

15. Knizhnikova S.V. Pedagogical prevention of suicidal behavior based on the formation of resilience. Krasnodar: ABC-polygrafiya, 2009: 111 p. (in Russian)

16. Craig G. Psychology of development Saint-Petersburg: Piter, 2011: 939 p. (in Russian)

17. Mendelevich V.D. Psychology of deviant behavior. SaintPetersburg: Rech', 2005: 444 p. (in Russian)

18. Goneev A.D., Lifintseva N.I., Yalpaeva N.V. Fundamentals of correctional pedagogy: Textbook. In: V.A. Slastenin (ed.). Moscow, 2017: 701 p. (in Russian) 